\title{
Az overtourism hatása a városi közlekedés átalakulására Budapesten
}

\author{
A turizmus talán minden eddigi növekedési ütemét, nagyságát meg- \\ haladó világméretű és hazai mértéke rendkívül indokolttá teszi az ez- \\ zel járó hatáselemzéseket. Tekintettel arra, hogy nemzetgazdasági je- \\ lentősége mellett a turizmus közlekedési hatásai is számottevők fontos \\ a téma sokoldalú megközelítése.
}

DOI 10.24228/KTSZ.2019.4.4

\section{Dr. habil Remenyik Bulcsú PhD - Sikó Botond - Huszár Péter

$\begin{array}{ccc}\text { egyetemi docens } & \text { PhD hallgató } & \text { PhD hallgató } \\ \text { Budapesti Gazdasági Egyetem } & \text { Szent István Egyetem } & \text { Szent István Egyetem } \\ \text { e-mail: remenyik.bulcsu@ } 0 \text { uni-bge.hu } & \text { sikoboti@gmail.com } & \text { phuszar@gmail.com }\end{array}$

\section{BEVEZETÉS}

Az overtourism az UNWTO (2018) (Turisztikai Világszervezet) általi megfogalmazás szerint „a turizmus azon hatása egy adott desztinációra vagy annak egy részére, amely negatívan befolyásolja a városlakók életminőségét és/vagy a látogató élményét" (UNWTO, 2018). A túlzott turizmus hatásai azonban korántsem csak társadalmi problémák területén láthatók, hasonló gondokat jelentenek a gazdaságban és a közlekedésben. A túlturistáskodás első negatív jelei a nagyobb repülőtereknél és a szállodaiparban mutatkoznak [8], aminek elemzésére vállalkozik a tanulmányunk.

Jelenleg az overtourism Európában sújtja leginkább. A város lakosságához képest ötször több turista érkezik egy évben a településre, ami már elviselhetetlenné teszi a helyiek életét. Nyilván Budapesten még messze nem tartunk ott, mint a katalán fövárosban, azonban fel kell készülni hasonló jelenségekre. A Nemzeti Turizmusfejlesztési Stratégia 2030-ra a turizmus ágazat jelenlegi nem egészen $10 \%$-os részesedését a GDP-ben 16\%-ra kívánja növelni, és közel 840 milliárd forint fejlesztéssel számol. Várható, hogy a duplájára is növekedhet a fövárosunkba látogató külföldi turisták száma, aminek a kezelése Budapest számára már komoly gondokat okozhat.

\section{AZ OVERTOURISM HATÓ TÉ- NYEZÖI ÉS KEZELÉSI LEHETÖ- SÉGEI}

A HOTREC (2018) (az EU országok szálloda, étterem és kávéházi szövetségek konföderációja) öt, a jelenség kialakulásával szorosan öszszefüggő faktort állapított meg az overtourism kialakulásának magyarázataként, a szervezet az indikátorok közül leginkább a diszkont légitársaságok által kínált olcsó jegyárakat, az egyszerủ foglalási rendszereket, az Y generáció költési hajlandóságát, a magánlakások (Airbnb) kiadását és a bakancslistás turizmust hibáztatja a helyzet kialakulásáért. Az UNWTO a szöuli konferenciáján (2018-ban) összesen hét stratégiát fogalmazott meg a városba áramló látogatók kezelésére, azonban a probléma megoldása során ezek az intézkedések eddig nem vezettek sikerre (1. ábra). 


\section{Szezonalitás csökkentése}

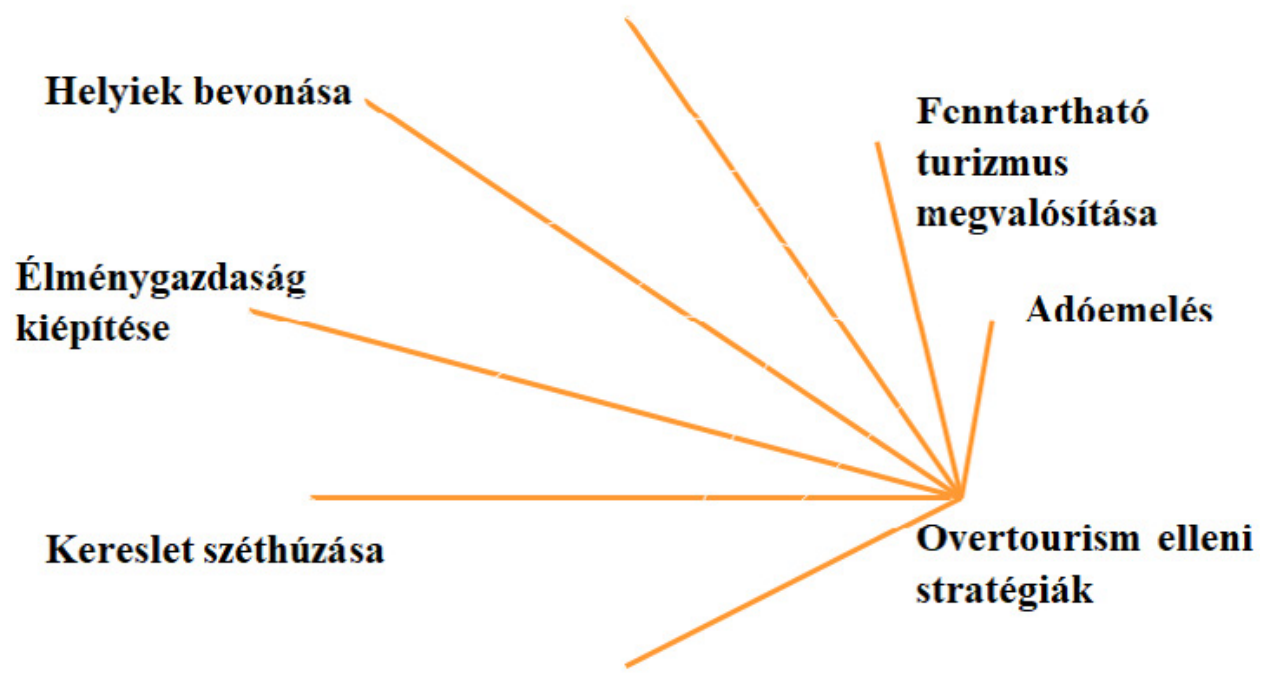

Kereslet diverzifikálása

A barcelonai és az amszterdami példákat elemezve elmondható, hogy fövárosunkban már most fontos lenne a helyi szolgáltatókkal és lakosokkal a kommunikáció és a kapcsolattartás erősítése. A látogatókkal való kommunikáció során fel lehetne hívni a figyelmet a turizmus okozta negatív hatásokra, így bíztatva őket a felelősségteljesebb viselkedésre („Élvezd és Tiszteld” szól az amszterdami felhívás). Ez történhet a helyiek bevonásával, vagy marketing és kommunikációs eszközök alkalmazásával is [7]. Abban az esetben, ha a látogatók részletes tájékoztatást kapnának a helyi szokásokról, kultúráról, valamint infrastrukturális rendszerről, könnyebben igazodnának a helyi élethez, így biztosan enyhülne a lakosok irritációja, mi több, a látogatóknak még autentikusabb élményt biztosítanának.

\section{AZ OVERTOURISM HATÁSA A HAZAI LÉGI KÖZLEKEDÉS ÁTALAKULÁSÁRA}

A KPMG Zrt. vizsgálatai szerint a túlzott turizmus egyik jele, hogy bizonyos pontokon kapacitásszüke kezd kialakulni. A Liszt Ferenc Nemzetközi Repülőtér forgalma 2013-ról 2018-ra 8,5-ről 15 millió utasra nőtt, és a föszezonban telítetté vált (1. táblázat). A 2019-es év elején indult el a repülőtér átfogó fejlesztési programja, aminek a keretében a repülötér üzemeltetője egy parkolóház, jövőre pedig egy új terminál építésébe is belekezd ${ }^{1}$.

A bejelentett fejlesztések szükségszerüségét egyértelmüen az overtourism jelensége kényszerítette ki. A kialakult áldatlan állapotokat csak egy új terminál felépítésével lehet orvosolni. A túlzott turizmus hatásait elemezve a Wizzair vezérigazgatója (a Budapest 2030-as konferencián bejelentette), hogy a diszkont légitársaság olyan fejlesztésekbe kezd, aminek következtében 2030-ban a repülötér forgalma eléri a 30 millió föt ${ }^{2}$. A fejlődésnek azonban vannak negatív hatásai is. A megnövekedett

\footnotetext{
1 https://budflyer.blog.hu/2018/05/03/igy_fejlodik_az_elkovetkezo_ evekben_a_budapest_airport

2 https://www.portfolio.hu/rendezvenyek/eloado/varadi-jozsef/7190
} 
forgalom ellen folyamatosan tüntetnek a repülőtér közelében élők. A főpolgármester közbenjárására augusztustól éjféltől hajnalig már nem landolhatnak gépek Ferihegyen, és szóba került a „fapados” járatok elköltöztetése is. A „fapados” légitársaság erre úgy reagált, hogy a legmodernebb Airbus repülőgépeket fogják beszerezni, amelyek 20\%-kal kevesebb üzemanyagot használnak fel, jobb lesz a helykihasználtságuk és sokkal halkabbak lesznek elődeiknél.

\begin{tabular}{|c|c|c|c|}
\hline Időszak & $\begin{array}{c}\text { Szállított } \\
\text { utasok } \\
\text { száma }\end{array}$ & Induló & Érkező \\
\hline 2010 & 8190089 & 4122453 & 4067636 \\
\hline 2011 & 8920653 & 4486933 & 4433720 \\
\hline 2012 & 8504020 & 4284374 & 4219646 \\
\hline 2013 & 8520880 & 4294764 & 4226116 \\
\hline 2014 & 9155961 & 4610675 & 4545286 \\
\hline 2015 & 10298963 & 5195866 & 5103097 \\
\hline 2016 & 11441999 & 5771010 & 5670989 \\
\hline 2017 & 13097223 & 6592317 & 6504906 \\
\hline 2018 & 15010000 & 7610000 & 7400000 \\
\hline
\end{tabular}

A Központi Statisztikai Hivatal (2007-2018 közötti) adatait elemezve megállapítható, hogy a legtöbb utas Németországból érkezik hazánkba (a szállított utasok száma 2007ben e viszonylatban 1453033 fö, 2018-ban 2144710 fö). A Malév 2012-es csődje és a nemzeti légitársaság hiánya leginkább az Egyesült Államokból érkezők számát érintette (a szállított utasok száma 2007-ben 143207 fö, 2018ban 128982 fő volt). A szállított utasok számában a legnagyobb növekedést Katar érte el (2007-ben 0, 2018-ban 167532 fö). Az utóbbi éveket nézve a kínai turisták számában jelentkezett jelentős növekedés (2014-től Budapest felkerült a javasolt desztinációk sorába). A terrortámadások hatása a Tunéziával kialakult légi kapcsolatainkat vetette leginkább vissza (az utasforgalom 2007-ben 97285 föröl 2018-ban 26794 forre csökkent). A legkereset- tebb célpontnak továbbra is London számít, leginkább az Egyesült Királyságban dolgozó magyarok miatt.

A beutazóturizmus igazi nyerteseinek Izrael (2007-ben 199872 fö, 2018-ban 448666 fö), az Egyesült Királyság (2007-ban 915363 fö, 2018-ban 2109792 fö), Franciaország (2007-ben 190689 fö, 2018-ban 694628 fö) és Hollandia számítanak (2007-ben 415582 fö, 2018-ban 760937 fö). Viszonylag jelentős utasforgalmat realizálunk a szomszédos országokból, legtöbben Lengyelországból (2007-ben 128645 fö, 2018-ban 284026 fö) és Romániából (2007-ben 294447 fö, 2018-ban 152918 fó) érkeznek.

A magyarok számára kedvelt desztinációvá vált Málta (az utasforgalmi adatok alapján 2007-ben 18043 fö, 2018-ban 86531 fö), Norvégia (81 974 fö, 217086 fö), Olaszország (574 550 fö, 1251888 fö), Oroszország (119 996 fö, 464047 fö), Portugália (46 330 fő, 214016 fö), Spanyolország (304 127 fö, 928773 fö), Törökország (179 076 fö, 475322 fö).

\section{A REPÜLÖTÉREN KIALAKULÓ TÚLZOTT TURIZMUS HATÁSAI A KÖZÖSSÉGI KÖZLEKEDÉSRE}

Fővárosunkban a korábban sokat elemzett közösségi közlekedés átalakulóban van [2]. A megosztott gazdaság (sharing economy) rendszere egyre több közlekedési eszközt tesz a turisták számára könnyen elérhetővé. Azonban a repülötérre érkező látogatók jelenleg még taxival vagy autóbusszal érhetik el a fövárost. A kérdőíves felmérésünket 2018 márciusában (a repülőtér és a Deák Ferenc tér között közlekedő) 100-as autóbuszon végeztük, az utazásnak ezt a formáját a tavalyi évben több mint egymillió utas vette igénybe. ${ }^{3}$ Felmérésünk szerint a látogatók $60 \%$-a szabadidős tevékenység, városlátogatás céljából érkezett a fóvárosba, míg 30\%-nál a tanulás volt a motiváló tényező, a maradék hozzávetőlegesen $10 \%$ rokonlátogatási vagy üzleti céllal jött Budapestre. A kutatásban résztve-

3 file:///C:/Users/Tan\%C3\%Alr/Downloads/Ker\%C3\%A9kgy\%C3\%Al rt\%C3\%B3_J\%C3\%A1nos.pdf 
vők nagy részét a 18-32 éves korosztály adta, ez valószínűleg több pontban befolyásolta a kapott eredményeket is. A 40 év feletti korosztály csupán 16\%-kal képviselte magát. A MONITOR által végzett vizsgálathoz (1999) viszonyítva elmondható, hogy a turisták számára 2019-ben is gondot okozott a repülőtérről a városba való bejutás. A kérdőíves elemzésből az is kiderült, hogy a helyzet csak az utóbbi két évben kezdett javulni, mióta a 100-as autóbusz a belvárossal való közvetlen összeköttetést lehetővé teszi. 1999-hez képest javult a vasúti megközelíthetőség, és a tervek szerint gyorsvasút is épül a főváros és a Liszt Ferenc Nemzetközi Repülőtér között.

A külföldi látogatók számára a legfőbb információforrásnak a Budapesti Közlekedési Központ (BKK) által kiadott online tájékoztató anyagok számítanak. Ebben sokat segít számukra a BKK Futár, a BKK Info és a repülőtéren lévő BKK információs iroda (https://bkk. hu/en/tickets-and-passes/prices/).

Bár a turisták elég nagy hányada nyilatkozott úgy, hogy minden információhoz hozzájutott, azonban ez talán nem volt elégséges, ugyanis a jegy- és bérletértékesítéseket tekintve tisztán látszik, hogy a különböző kedvezményes csomagokat nem vették igénybe. A válaszadók több mint fele utazott vonaljeggyel, azonban az is kimutatható, hogy egyre többen használják ki a Budapest Kártya nyújtotta előnyöket. A megkérdezettek szerint a Budapest Kártya telefonos applikációs rendszerre való váltása további nagy lehetőségeket hordoz.

Egy kérdéssor azt volt hivatott felmérni, hogy az utazók a városban melyik közlekedési eszközt használják. Az adatokat összegezve a legtöbben a metrót használták, a használatba vétel okaként pedig annak sebességét jelölték meg. A második legnépszerübb eszköz a villamos, elsősorban szintén gyorsasága és a dugók elkerülése miatt. A praktikusságot mindkét jármü esetében viszonylag sokan kiemelték. Többen megjelölték a taxit is, de használata nagymértékben háttérbe szorult a többi jármüvel szemben. Itt a motiváló tényezőket a sebesség, a kényelem és az egyéb opciók hiánya jelentették. Az adatok számsze- rű elemzése azt mutatta, hogy a válaszadók $80 \%$-a vette igénybe a metrót, ezt követte a villamos és az autóbusz használata 74 illetve 58\%-kal. A külföldi turisták a fövárosban előszeretettel használják az 1- es és a 2-es metró, a 7-es autóbusz és a 2-es, 4-es és 6-os villamosok vonalát.

A megkérdezettek a járatok késését, a lopást és az utastársak viselkedését említették negatívumként, de a BKK alkalmazottak hozzáállását is kritizálták. A közösségi közlekedés fent említett elemeit tovább vizsgálva árnyaltabb kép bontakozott ki. Az ellenőrök segítőkészségét, felkészültségét, nyelvtudását a megkérdezettek leginkább közepesre vagy annál alacsonyabbra értékelték. Az eszközök / jármüvek esetében is inkább negatív volt a visszajelzés. Mind a tisztaság, megbízhatóság és az általános állapot tekintetében is vannak elmaradásai a fővárosnak és az üzemeltetőknek. A külföldi vendégek számára a tájékozódás legfontosabb részei lehetnének az idegen nyelvű információforrások, amelyeket akár vizuális technológiával, akár külön pultok felállításával, vagy legegyszerübb módon a jelenlegi tájékoztatási rendszerek kibővítésével, fejlesztésével lehetne elérni. Ezeket vizsgálva szintén elmaradásban van a fóváros.

Arra a kérdésre, hogy szoktak-e jegyet váltani Magyarországon, a válasz egyértelmüen az 'igen' volt, majdnem 100\%-os aránnyal. Ezek közül kiemelkedik a sima vonaljegy, valamint a napijegy, $10 \%$ vallotta, hogy Budapest Kártyát vásárolt.

A válaszadók általános véleménye a magyar fövárosban való tartózkodásról pozitívnak tekinthető, 90\% volt elégedett az itt eltöltött idővel. A közösségi közlekedésről alkotott vélemények már nem ilyen pozitívak, de nagyrészben itt is a 4-es osztályzat volt a meghatározó.

A fejlesztések átstrukturálták a taxi és turizmus viszonyát is. Míg korábban a repülőtér, a szálloda és az attrakciók között müködött a legtöbb fuvar, addig mára a legtöbb utazás a bulinegyedbe történik [3]. A kerületek közötti egyensúly is felbomlott, jelenleg az V., a VII. és az I. kerületbe történik a legtöbb utazás. 
A taxivállalatok számára a repülőtéri utazások tekintetében az üzleti- és konferenciaturisták számítanak a legfőbb szegmensnek.

A külföldi utazók véleményének hatására a BKK komoly változtatásokat tett a közösségi közlekedés átalakítására. Valójában ennek köszönhető a jó osztályzat is. Nagy lemaradás a konferenciaturisták igényeinek a kielégítése terén látszik. Már az 1990-es évektől tervbe vették egy gyorsabb összeköttetés létrehozását a repülötér és a belváros között, ami mind ez idáig nem valósult meg.

\section{AZ OVERTOURISM HATÁSA A FÖVÁROS TURIZMUSÁRA}

A MONITOR 1999-es kutatásához képest Budapest közlekedésének átalakulására nagy hatást gyakorolt a bulinegyed létrejötte. Az általunk megkérdezettek a hely imázsát tartották a legfontosabb vonzerőnek, és hogy a bulinegyed nemzetközi hírü brandet épített ki magának. Kiemelték továbbá a romkocsmaturizmust, mint sajátosságot, ami külön autentikussá teszi a települést, helyi életformát jelenít meg. Szerintük a bulinegyed vonzereje annak köszönhető, hogy Budapesten van és jól megközelíthető helyen található, ahonnan éjszaka is eljuthatnak mindenhová. További kiemelésre került a barátok jelenléte, a nemzetközi jelleg, a multikulturális települési rang. A biztonságos város kérdése is a központi elemek közé tartozott. Felmérésünk szerint egy buliturista hétvégére érkezik a fövárosba, szívesen veszi igénybe diszkont légitársaságok szolgáltatásait és alszik Airbnb-ben (egyedi szálláshelyeket kereső és kiadó rendszer). A föváros kivételével más településekre nem látogat el. Az itt töltött idő alatt minél többet akar látni Budapestből. A fejlődésnek azonban ára is van, mert a helyi lakosok turista ellenes gyüléseket rendeznek a nagyobb köztereken, folyamatosan „harcolnak” az önkormányzattal az éjszakai nyugalom megvalósításáért. A sikertelen népszavazási kísérlet után felgyorsult a korábbi „őslakosságnak” a kerületből való elköltözése is.

A „sharing economy” rendszere elöször a szálláshelyek területén okozott változásokat.
Jelenleg a fővárosi szállodák számára az igazi nagy versenytársnak az Airbnb-k számítanak. A „magánlakások” előtérbe kerülése a hostelek az egy-, kettőcsillagos szállodák vendég- és vendégéjszaka számaiban jelentős viszszaesést okozott.

Ha eltekintünk a csillagfokozatok szerinti elkülönítéstől, akkor a külföldi vendégek száma nagyon szép növekedést mutat a budapesti szállodák tekintetében (2010 és 2017 között majdnem 1,3 millió fővel gyarapodott a létszámuk). Igaz az átlagos tartózkodási idő még mindig alacsonynak mondható (2,4 éjszaka), azonban a külföldiek által eltöltött vendégéjszakák száma ezen időszak alatt megduplázódott. 2010 és 2017 között a kereskedelmi szálláshelyeken a belföldi vendégek- (183 ezer fővel) és vendégéjszakák száma (302 ezerrel) növekedést mutat, de a tartózkodási idő továbbra is nagyon alacsonynak számít (1,9 éjszaka).

Az egyéb szálláshelyek tekintetében mind a külföldi vendégek száma, mind az általuk eltöltött vendégéjszaka szám szintén megduplázódott 2010-hez képest. A tartózkodási idő a 2012-es évben volt a legmagasabb, ami a legnagyobb forgalmú turistaországok számára is irigylésre méltó adat (4,3 éjszaka).

Az egyéb szálláshelyeken nagy növekedésnek indult a belföldi vendégszám. Különösen a 2017-es év számít kiugrónak (a 2016-os 138 ezerről, 2017-ben 211 ezer före emelkedett). Az átlagos tartózkodási idő azonban itt is visszaesett az országos átlag szintjére (2,5 éjszaka), ami azt jelenti, hogy a turisták többször jönnek a fövárosba, de ott rövid időt töltenek el (hosszú hétvégeket).

A müködő kereskedelmi szálláshelyek száma szignifikáns növekedést mutat 2010-hez képest, ha hozzászámoljuk a közeljövőben átadandó $15 \mathrm{db}$ szállodát, akkor Budapesten az elmúlt kilenc év alatt 56 darab új hotelt adtak át. Ugyanígy a következő évben a kiadható szobák száma is 20000 -röl 24 000-re növekszik majd, ez azt jelentené, hogy a fövárosban az overtourism hatására 3 év alatt 4000 darab új szoba létesült. 
A KSH adatai szerint 13885 darab szobát tartanak számon az egyéb szálláshelyek között. A Magyar Szállodák és Éttermek Szövetsége szerint ebböl 9000 darab szoba Airbnb, 4885 darab apartmanház. Más felmérések szerint 19498 Airbnb és 10576 felhasználó foglalkozik magánlakások kiadásával [1]. Tény és való, hogy nem mindegyik Airbnb van bejelentve az önkormányzatokhoz, azonban 2019 végére az új Nemzeti Turisztikai Adatszolgáltató Központ (NTAK) adatbázis számukra is regisztrációs kötelezettséget jelent majd a Magyar Turisztikai Ügynökség felé. A férőhelyek, a szobák, a vendéglátók és az ágyak száma nagyon dinamikus növekedést mutat 2010-hez képest.

\section{A VÁROSI KÖZLEKEDÉS ÁTALA- KULÁSA}

A „sharing economy” közlekedést átalakító jelei még csak kezdetleges formában láthatók a fövárosunkban. A megosztott gazdaság ebben az esetben azt jelenti, hogy az egyes eszközöket addig használjuk ameddig szükségünk van rájuk. Erre jó példa a MOL Bubi kerékpáros szolgáltatás vagy a MOL Limo autóhasználat is. A közösségi közlekedésben ilyen a vezető nélküli 4-es metró és a kísérleti szinten működő vezető nélküli villamosszolgáltatás. Az autóbusz-közlekedés vezető nélküli használatát a zalaegerszegi tesztpályán vizsgálják, ami szolgáltatásként jelenleg még csak Kínában müködik [9].

A városi közösségi közlekedésre vonatkozó kérdőívünket Budapesten, a Kossuth téren töltettük ki 2018 januárjában. A kutatásunk alapján elmondható, hogy a megkérdezettek a budapesti tartózkodás okaként nagyjából hasonló arányban jelenik meg a tanulás (27\%), a pihenés (26\%) és a rokonlátogatás (23\%). A közösségi közlekedéssel kapcsolatban a válaszadók nagy százaléka (70\%) az interneten keresztül tájékozódott, ennek ellenére (a vidéki közösségi közlekedéshez képest) kaotikusnak nevezte a főváros közlekedését. A megkérdezettek által vásárolt termékek $46 \%$-át a vonaljegyek teszik ki, ezt követi a bérlet (25\%), valamint a napijegy (14\%). A vonaljegyet használók 20\%-a bliccel, az okok között a jegyek drágaságát és a jármüvek állapotát jelölték meg.
A használt közlekedési eszközök közül a legtöbben a metrót a gyorsasága (85\%) miatt választották. A villamost a válaszadók 46\%-a szintén a gyorsasága miatt veszi igénybe, míg 25\%-uk azért utazik rajta, mert nincs más lehetősége.

A budapesti közösségi közlekedéssel kapcsolatban a leggyakrabban elhangzott pozitív vélemények közé tartozott a menetrendszerüség, a járatok gyakorisága, sürűsége, a várost jól átszövő hálózat és a jó átszállási lehetőségek. Ezzel szemben a negatív visszajelzések gyakoribbak voltak, mint az elégedettséggel kapcsolatos észrevételek. A legtöbben a jármüvek és a közlekedési infrastruktúra (aluljárók, megállók) állapotát sérelmezték. A járműveket (különösen az autóbuszokat, illetve a hármas metró vonalát) koszosnak, elavultnak tartják, negatívan értékelték a nagyszámú hajléktalan jelenlétét, ahogy a klíma, illetve az akadálymentesítés hiányát is.

A kérdőív eredményei szerint a magyar turisták körében több a negatív véleménynyilvánítás, mint a pozitív, de többen megjegyezték, hogy látják a változtatásokat, és a magyar / fövárosi (közösségi)közlekedési helyzet - ha lassan is - de jó irányba fejlődik.

Az újfajta rendszerek ismeretét és aktív használatát célzó kérdésre adott válaszok érdekesen oszlottak meg. A jegy- és bérletkiadó automaták közkedveltek, a válaszadók $85 \%$-a használja őket. A BKK Futár nevű online utazásszervező honlap és mobilalkalmazás segítségével a megkérdezettek 51\%-a szokta megtervezni útját. Ugyanennek az alkalmazásnak a járatfigyelő részét viszont csak 38\% használja. A szintén online és app formájában elérhető BKK Info járatinformációs szolgáltatást $26 \%$ veszi igénybe. Meglepő eredményt mutat az alkalmazáson leadott taxirendelések aránya, ez csupán alig 11\%-ot tesz ki.

A kutatás átfogó és nagyon érdekes része volt a szolgáltatás színvonalának megítélését célzó kérdés, valamint az ezen szempontok minőségének változását irányzó eredmények (2. ábra). A szolgáltatás színvonalát tíz különböző befolyásoló tényezőre osztottuk fel. Ezek voltak 


\section{2. ábra: A szolgáltatás színvonalának megítélése kïlönböző szempontok szerint, saját kutatás és szerkesztés [6]}

jármüvek állapota (korszerüség, higiénia, ...)

információszerzés (pl. üzemzavar esetén)

információszerzés (pl. menetrendről)

jegy- és bérletváltás módja

éjszakai vonalhálózat (menetrend)

éjszakai vonalhálózat (lefedettség)

nappali vonalhálózat (menetrend)

nappali vonalhálózat (lefedettség)

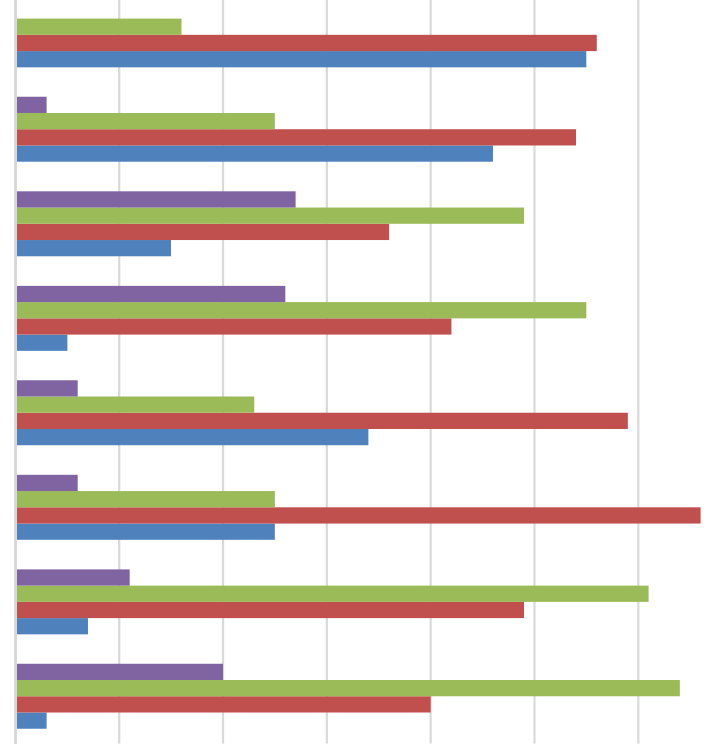

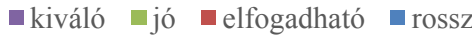

többek között a taxik megbízhatósága, mint például a korrekt árazás tapasztalása, a taxik mennyisége.

A válaszadók többségének meglátása szerint a taxik megbízhatósága elfogadható, a második helyen viszont a rossz megítélés következett. A nagy többség szerint ebben nem is tapasztalható minőségbeli változás. A taxik mennyisége a többség szerint elfogadható és jó. Itt sokan tapasztaltak pozitív változást. A következő szempont a közösségi közlekedés jármüveinek állapota volt. A jármüvek életkori statisztikái a fővárosban köztudottan nem jók, a tendencia viszont pozitívnak tünik az adatok és jármübeszerzési törekvések alapján. A kérdőívet kitöltők nagyrésze - fej-fej mellett - elfogadhatónak és rossznak ítélte meg ezt a minőségi szempontot. Bár a legtöbben javuló, de sokan megdöbbentő módon máig romló tendenciát érzékelnek. Három kérdés vonatkozott a már korábban is említett újfajta rendszerekre, kényelmi szolgáltatásokra. Kiemelendő, hogy a jegy- és bérletváltás módját, valamint a menetrendi információszerzést nagyon sokan jónak vagy legalább elfogadhatónak jelölték, sőt, számos kitöltő kiválónak minősítette ezeket. Ezen két szempont esetén a kitöltők óriási többsége javuló tendenciát is észlelt. Az üzemzavar esetén lezajló utastájékoztatás már árnyaltabb megítélést kapott, mivel közel ugyanannyian tekintették rossznak, mint elfogadhatónak, és kevesen jónak. A tendencia ebben az esetben a kitöltök nagyrésze szerint szintén javuló, de nagyon sokak szerint stagnáló.

További négy kérdést tettünk fel a nappali és az éjszakai vonalhálózattal kapcsolatban. A nappali vonalhálózat lefedettségét és menetrendjét a kitöltők nagyrésze jónak, valamint sokan elfogadhatónak jelölték meg. A legtöbben ezeknél javuló tendenciát, sokan stagnálást észleltek. Az éjszakai hálózat megítélése ennél negatívabb képet mutat. Kimagasló azok száma, akik csak elfogadhatónak értékelték ezt, és ugyanannyian tekintették jónak az éjszakai menetrendet és hálózati lefe- 
dettséget, mint rossznak. A válaszadók többsége ebben az esetben az jelölte be, hogy nem észlel változást, de számos kitöltő javuló tendenciát észlelt.

\section{7. ÖSSZEFOGLALÁS ÉS AJÁNLÁSOK}

Összegzésként megállapítható, hogy az overtourism hatásai a barcelonai vagy az amszterdami példákhoz képest még kevésbé láthatók fővárosunk közlekedésében. A Liszt Ferenc Nemzetközi Repülőtéren kialakult kaotikus viszonyok azonban már előre vetítik, hogy mi sem kerülhetjük majd el a rendszer átalakítását. Ezért egyre sürgetőbbe válik a fejlesztésekben megígért repülőtéri gyorsvasúti összeköttetés kiépítése, és a megosztott gazdaság közlekedési kiépítése. A sharing economy hatására megváltozik a turistáknak a városban történő mozgása is, háttérbe szorul a belvárosi autós közlekedés. A gyalogosforgalom mellett egyre nagyobb szerephez jut a bicikli és roller sáv, de az autóút mellett a vezető nélküli buszsáv is kiemelt figyelemben részesül majd. A fenntartható fejlődés megvalósítása érdekében egyre inkább kiszorulnak a belvárosból a benzin- és dízelüzemű autók, helyüket az elektromos MOL Limo flottához hasonló jármüpark veszi át. Újfajta jegytípusokkal és bővebb bérletkínálattal a helyiek és a turisták számára is könnyebbé és gazdaságosabbá lehet tenni a közösségi közlekedés használatát, ezzel pedig visszaszorítható a bliccelések és a negatív visszajelzések száma.

A budapesti közösségi közlekedés alakításában egyrészt figyelembe kell venni a helyi lakosság igényeit és elvárásait, fő kritikus szempontjait. Másrészt pedig fontos a közösségi közlekedés dinamikus fejlesztése a hazánkba érkező turisták összetételének, szokásainak, igényeinek trendjeit szorosan követve. A 100E repülőtéri autóbusz óriási sikere miatt bővíteni kell a szolgáltatást, illetve a repülőtéri információszerzést. A jegyvásárlás fejlesztése is szükségessé vált.

A járműveket és a kritikus pontokon történő utastájékoztatást illetően jelentős fejlesztések történtek, amit a jövőben folytatni kell. A közösségi közlekedést sok és sokfajta ember veszi igénybe. Mindegyik igénynek megfelelni nem lehet, de mégis igyekezni kell ennek elérésére. A budapesti közösségi közlekedés számos szempontból jól teljesít és fejlődik. Észre kell venni és alkalmazni a további innovációs lehetőségeket, valamint az eddigi törekvéseket folytatni kell a dinamikusan fejlődő várossal, lakosaival és látogatóival együtt.

\section{FELHASZNÁLT IRODALOM}

[1] Jancsik A.-Michalkó G.-Csernyik A. 2018: Megosztás megosztottság nélkül. - Közgazdasági Szemle 65(3), pp. 259-286.

[2] Jászberényi M.-Pálfalvi J. 2006: Közlekedés a gazdaságban. Aula Kiadó. Budapest 468p.

[3] Michalkó, G.-Hinek, M.-Jusztin, M.-Váradi, Zs.-Vizi, I. 2007: Taxi és turizmus: a taxiközlekedés szerepe Budapest nemzetközi vendégforgalmában. Turizmus Bulletin, X. évf. 3. szám, pp. 34-39.

[4] MONITOR Társadalomkutató Intézet és Módszertani Központ 1999: A külföldi turisták véleménye a budapesti tömegközlekedésről. Kézirat. Budapest.

[5] Remenyik B.-Szabó L.-Tóth G. 2014: Közlekedésföldrajz és turizmus Magyarországon. Dialóg-Campus Kiadó. Budapest, 164p.

[6] Remenyik B.-Sikó B.-Szabó L.-Guth L. 2018: The Relationship between Public Transport and Tourism in Budapest pp. 33-34. In: Nataša, URBANČÍKOVÂ (szerk.) Smart Communities Academy: Proceeding of Abstracts Košice, Szlovákia : Technical University of Kosice, (2018) p. 51

[7] Remenyik B.-Szabó L. 2019: Világturizmus. Dialóg-Campus Kiadó. Budapest, 219p.

[8] Remenyik B.-Szabó L.-Sikó B. 2019: Az overtourism hatásai a szállodaiparra. Gazdálkodás 19/2. (megjelenés alatt)

[9] Vitézy D. 2019: Innovatív megoldások a városi közlekedésben. In: Jászberényi M.Munkácsy A.: Innováció és közlekedés. Konferenciakötet. (megjelenés alatt).

[10] https://bkk.hu/fejlesztéseink.hu

[11] ht t p s://bkk.hu/w p - content/ uploads/2012/04/Varosnezo_BKK_ szabalyozasi_koncepcio.pdf

[12] file://C:/Users/Tan\%C3\%A1r/Downloads/ Ker\%C3\%A9kgy\%C3\%A1rt\%C3\%B3_J\%C 3\%A1nos.pdf 
[13] https://budflyer.blog.hu/2018/05/03/ igy_fejlodik_az_elkovetkezo_evekben_a_ budapest_airport

[14] https://bkk.hu/en/tickets-and-passes/ prices/
[15] www.unwto.org

[16] www.hotrec.eu

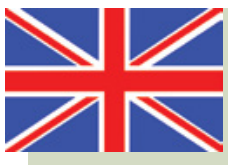

\section{The impact of overtour- ism on the transforma- tion of urban transport in Budapest}

The global and domestic scale of tourism has exceeded perhaps all of its previous growth rates. This makes impact analyses focusing on the issue of overtourism highly justifiable. Besides its significance in national economy, the impact of tourism on the transport system is also considerable. Considering this, a multidimensional approach of the topic is important.

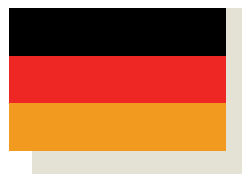

\section{Der Auswirkungen de Overtourismus auf die Umwandlung des Stadt- verkehrs in Budapest}

Der weltweite und inländische Fremdenverkehr, der vielleicht alle bisherigen Wachstumsraten übertroffen hat, macht es sehr gerechtfertigt, die damit verbundenen Analysen durchzuführen. Mit Hinsicht darauf, dass neben der Bedeutung des Tourismus für die Volkswirtschaft auch seine Auswirkungen für den Verkehr beachtlich sind, ist eine mehrdimensionale Betrachtung des Themas erforderlich.

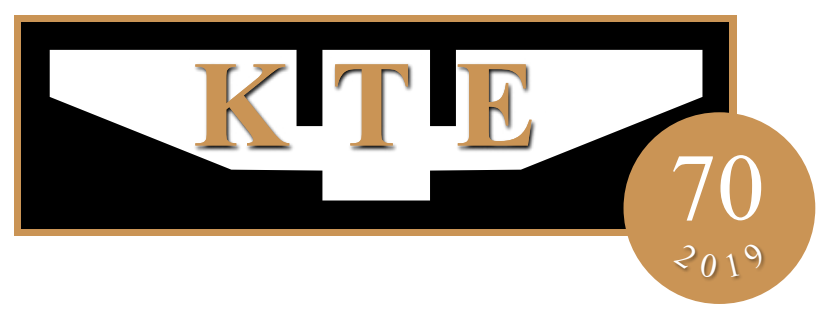

